Preferences for Paid Paternity Leave Availability, Lengths of Leave Offerings, and Government Funding of Paternity Leaves in the U.S.

\author{
Chris Knoester* \\ Ohio State University \\ Qi Li** \\ Ohio State University
}

Suggested Running Head: Paid Paternity Leave Preferences in the U.S.

Keywords: paternity leave, fatherhood, parental leave, parenting, work-family

*Please direct all correspondence to Chris Knoester, 152 Townshend Hall, 1885 Neil Ave, The Ohio State University, Columbus, OH 43210 (knoester.1@osu.edu), Ph:

614-247-7261 (work), 614-725-0075 (home), fax: 614-292-6687.

** Qi Li, Department of Sociology, 1885 Neil Ave, The Ohio State University, Columbus, OH 43210 (li.6109@buckeyemail.osu.edu), Ph: 614-292-6681, fax: 614292-6687.

***This is a peer-reviewed preprint of the article:

Knoester, Chris, and Qi Li. "Preferences for Paid Paternity Leave Availability, Lengths of Leave Offerings, and Government Funding of Paternity Leaves in the U.S." Available Online First in Sociological Perspectives. Copyright $\mathbb{C}$ [2021] (Sage). DOI: https://doi.org/10.1177/07311214211001892. 


\begin{abstract}
This study analyzes 2012 General Social Survey data $(N=1,089)$ about preferences for paid paternity leave availability, lengths of leave offerings, and government funding of leaves. It highlights gender and gendered parenting role attitudes as predictors of leave preferences. Descriptive results revealed sizable (i.e., 53\%) support for leave availability and moderate (i.e., 33\%) support for some government funding; still, only modest (i.e., 5 weeks) lengths of leave offerings were desired. Regression results indicated that women were typically more likely than men to support more generous leave offerings. Consistently, dual-earner expectations were positively associated with preferences for more generous leave offerings. Separate spheres attitudes appeared to be meaningful for women's preferences, but not for men's preferences. Importantly, the findings from this study suggest that there have been longstanding preferences for more generous and widespread paid paternity leave offerings in the U.S.- and more public policy action is long overdue.
\end{abstract}




\section{Preferences for Paid Paternity Leave Availability, Lengths of Leave Offerings, and Government Funding of Paternity Leaves in the U.S.}

Evidence continues to accumulate that paternity leave-taking is associated with positive outcomes for families. In the U.S., paternity leave-taking appears to encourage father involvement, quality father-child relationships, parents' relationship quality, and parents' relationship stability (Knoester et al. 2019; Petts et al. 2020; Petts and Knoester 2018; 2020; Pragg and Knoester 2017). It may also reduce work-family conflict, increase gender equity at home and in the workplace, reduce mothers' stress, boost mothers' participation in paid work, and lead to increases in family incomes (Gault et al. 2014; Petts and Knoester 2020; Raub et al. 2018).

To a great extent, paternity leave-taking appears to be symbolic and effective because it challenges traditionally gendered expectations in parenting commitments, paid work commitments, and gender inequalities - and encourages and supports fathers in taking time off from paid work for the purpose of devoting time and energies towards domestic responsibilities (Gault et al. 2014; Petts and Knoester 2020; Raub et al. 2018). In fact, paternity leave offerings are often devised for the purpose of addressing gender inequalities and incentivizing fathers to become more involved in family life. Yet, there is increasing demand for such programs from current and prospective fathers, as well (Harrington et al. 2018; Petts et al. 2018; Raub et al. 2018). Overall, the structural support provided by paternity leave offerings can help to enable couples to more closely adhere to their ideals of dividing paid work and family responsibilities, ideals that increasingly indicate a preference for more gender egalitarianism (Gerson 2009; Pedulla and Thébaud 
2015; Thébaud and Pedulla 2016). Thus, paternity leave offerings may encourage and model resistance to the common trend of couples realizing especially traditionally gendered divisions of domestic and paid work after the birth of a child (Bianchi et al. 2006; Gerson 2009; Petts et al. 2018; Yavorsky et al. 2015). In addition, paternity leave offerings can function to normalize parental leave offerings and leave-taking, generally. They can also challenge traditionally gendered and institutionalized "ideal worker" norms in workplaces (Acker 1990; Petts and Knoester 2020; Pedulla and Thébaud 2015).

Paid paternity leave, as opposed to any paternity leave (i.e., either paid or unpaid), is important to focus upon because fathers are especially sensitive to the incentives that are offered as part of paternity leave offerings (Harrington et al. 2014; Petts et al. 2018). That is, they are more likely to take (longer) leave if it is compensated-- especially at a high level. Yet, less than $20 \%$ of worksites offer paid paternity leave to most employees and the U.S. is a rarity among OECD nations in not guaranteeing paid leave to fathers of infants (Petts et al. 2018; Raub et al. 2018). In all, through some combination of different types of paid leave offerings (i.e., often vacation and sick days), $20-40 \%$ of fathers seem to take some amount of paid leave after the birth of a child. Although, some states have begun to pass and implement paid family leave legislation such that seven states (plus Washington, D.C.) will have forms of paid parental leave put into practice by 2021 (Harrington et al. 2014; Kaufman 2020; Petts et al. 2018; Raub et al. 2018; Scarborough et al. 2018).

Attitudes about paid paternity leave are important to investigate because they can reveal measures of support for paid paternity leave policies, symbolize expectations for 
fathering in the midst of breadwinning pressures, and enable analyses of the extent to which gendered expectations shape paternity leave preferences. These attitudes can also influence the structures, cultures, and practices of workplaces in America (Author Citation; Harrington et al. 2014; Milkman and Appelbaum, 2013; Pedulla and Thébaud 2015; Thébaud and Pedulla 2016).

Therefore, this study assesses U.S. attitudes about paid paternity availability, preferred lengths of paid paternity leave offerings, and government support of leaves. First, we describe the nature of support for these dimensions of paid paternity leave offerings. Then, we focus on individuals' internalized gendered expectations in differentiating support for more generous paid paternity leave offerings; that is, we examine the extent to which gender and gendered parenting role attitudes shape paternity leave preferences. We expect that women and those with less traditionally gendered attitudes about involved fathering commitments, dual-earner couples, separate spheres, and intensive mothering will be especially likely to support more readily available paternity leave offerings.

The present study advances the limited research on attitudes about paid paternity leave in the U.S. In particular, the present study complements and extends more recent, basic descriptive information about paternity leave (e.g., Pew Research Center 2017). Also, it specifically builds upon and extends prior work that utilizes the best available data for comprehensive analyses of U.S. paternity leave attitudes, the 2012 General Social Survey (GSS). Petts et al. (2018) use these data to briefly present a snapshot of support for any paid paternity leave availability, before focusing their analysis on 
reported leave-taking in multiple prominent social science data sets. Also, Valarino et al. (2018) use these data, in combination with the 2012 International Social Survey Programme, to engage in a cross-national comparison of attitudes about preferred lengths, gendered divisions, and funding source of parental leave-taking among U.S., Austrian, Swedish, and Swiss adults—but do not focus on paternity leave-taking or patterns within the U.S., specifically. Neither of these studies that use the GSS data comprehensively theorize or test how multidimensional aspects of gender ideologies shape paternity leave attitudes in their analyses, either.

Specifically, the present research advances understanding by comprehensively: a) examining preferences for paid paternity leave offerings that include leave availability, desired lengths of offerings, and government funding for leaves among a national sample of U.S. adults, b) theorizing about why mismatches (i.e., substantial public opinion support but scant institutionalized support) are expected to exist between public opinions and public policies, c) focusing on how gendered expectations that are linked to gender and gendered parenting role attitudes may shape paid paternity leave preferences, d) considering the multidimensional aspects of gender ideologies in predicting leave preferences, and e) analyzing the most recent and comprehensive information on public opinions about paternity leave in the U.S. that allow for multiple regression analyses in order to distinguish how prominent social forces work together to influence paternity leave attitudes.

We find evidence of sizable (i.e., 53\%) public opinion support for paternity leave availability and moderate (i.e. 33\%) support for some government funding of such leaves 
that has been apparently longstanding — since 2012. Yet, there is only an expressed desire for modest (i.e., 5 weeks) lengths of paternity leave offerings. Regression results suggest that gender and gendered parenting role attitudes significantly distinguish adults' paid paternity leave preferences. In particular, women are more likely than men to support generous paid leave offerings. Also, dual-earner expectations appear to consistently encourage preferences for more generous paternity leave offerings. Attitudes about separate spheres also seem to be influential; yet, they interact with gender such that separate spheres attitudes appear to affect women's paid paternity preferences but not men's preferences.

\section{CONCEPTUAL FRAMEWORK}

The conceptual framework for this study highlights gendered expectations as prominent influences in the formulation of preferences for paid paternity leave offerings. This emphasis stems from sociological work that recognizes how gender structures society through institutional patterns and logics but also shapes the expectations and experiences of individuals in myriad ways (Lorber 1995; Ridgeway 2009; Risman 1998). For example, gender is embedded in institutionalized practices and profoundly influences the formation of social identities, role expectations, and worldviews (Hays 1996; Risman 1998; Scarborough et al. 2018). We focus on individuals' reports of their gender and gendered parenting role attitudes as indicators of how gendered expectations are negotiated and internalized by individuals within the U.S. social context. Gendered parenting role attitudes involve beliefs about involved fathering commitments, dualearner couples, separate spheres of specialization, and intensive mothering. 
Our understanding of gendered expectations extends from Risman's $(1998 ; 2018)$ conceptualization of gender operating as social structure at the individual (e.g., directs beliefs, identities, aspirations, behaviors), interactional (e.g., encourages particular expectations, decisions, and reactions in social interactions), and institutional (e.g., gendered assumptions are embedded in institutions and their logics and practices) levels. Cultural practices and beliefs pass down, direct, and generally reinforce extant gendered understandings and experiences - but can also encourage changes as cultural values shift and individuals resist traditional ways of doing things (Risman 1998; 2018). Essentially, we view gendered expectations as the culmination of gender acting as social structure. Yet, individuals have some agency in recognizing, responding, and offering challenges to gendered expectations that derive from gender as social structure, within their cultural milieus (Risman 1998; 2018; West and Zimmerman 1987).

We integrate the recognition of the salience of gendered expectations with political science theorizing and research on public opinions about family social policies. This work notes the importance of institutional, self-interest, and ideational factors in affecting attitudes about public policies (Blekesaune and Quadagno 2003; Valarino et al. 2018). Institutional influences refer to the characteristics, structures, and policies within nations. Self-interest influences involve the propensity of individuals to support policies that they believe will personally benefit them. Finally, ideational influences refer to the ways that subjective perceptions shape policy preferences such as through the influence of the identities, role expectations, and worldviews of individuals (Blekesaune and Quadagno 2003; Valarino et al. 2018). Consequently, in sum, our conceptual framework 
leads us to examine how gendered expectations-- as connected to institutional, selfinterest, and ideational factors-- are likely to affect public opinions about paid paternity leave offerings. Yet, we focus on the relevance of gender and gendered parenting role attitudes as indicators of internalized gender expectations.

Institutional Contexts and Preferences for Paid Paternity Leave Offerings in the U.S.

Despite having enormous financial resources, the U.S. is a rarity among countries with developed economies in not guaranteeing paid paternity leave offerings for its citizens. In fact, over $94 \%$ of OECD countries guarantee paid leave to fathers of infants; over half of these countries guarantee at least 6 months of paid leave to fathers, and over 2/3 guarantee at least 3 months (i.e., 14 weeks) of paid leave. Furthermore, in order to incentivize paternity leave-taking, most OECD countries offer at least 2 weeks of paid leave that is reserved for fathers; some countries offer a financial bonus for paternity leave-taking, too (Gault et al. 2014; Raub et al. 2018).

In the U.S., less than $20 \%$ of fathers have access to paid paternity leave. Also, there are enormous disparities in access depending on where one lives and who one's employer is. More advantaged fathers (i.e., high SES, white, married) are much more likely to have access to paid leave compared to more disadvantaged fathers. Also, fathers in the handful of states that have passed paid family leave policies can draw upon state programs to fund their leaves - usually at lower levels of wage replacement than typical OECD policies, though (Petts and Knoester 2020; Petts et al. 2018; Winston 2014). Largely because of the sparse (paid) leave offerings in the U.S., it seems, most fathers take one week or less of time off from work after the birth of a child — and it is typically 
unpaid leave (Harrington et al. 2014; Petts et al. 2018; Winston 2014). Although most workers are covered by the Family Medical Leave Act (FMLA) that guarantees unpaid family leave, approximately $40 \%$ of employees are not covered because of restrictions involving worker tenure (1,250 hours in the past year) and firm size (50+ employees).

There is some extant evidence of support for more generous paternity leave offerings in the U.S. (Harrington et al. 2014; Petts et al. 2018; Pew Research Center 2017; Valarino et al. 2018). Still, there are also concerns and pressures involving the consequences of paternity leave-taking. That is, workplace norms indicate that an ideal worker will not take much, if any, time off from work — even for the birth of a child (Acker 1990; Petts et al. 2018). Employees are often made aware of these expectations and understand that the consequences may, and often do, include resistance to requests for leave, correspondingly poor performance ratings, and lower future earnings (Coltrane et al. 2013; Rege and Solli 2013; Rudman and Mescher 2013). Furthermore, male breadwinning expectations are often internalized by individuals and/or their partners and these dynamics may negatively affect not only paid leave attitudes but leave-taking practices, too (Collins 2019; Petts and Knoester 2019; Pragg and Knoester 2017; Pedulla and Thébaud 2015; Thébaud and Pedulla 2016).

Nevertheless, we expect that public opinions about paid paternity leave will substantially support paid paternity leave availability, relatively long lengths of leave offerings, and some government funding of paid paternity leaves even within the U.S. institutional context. Parenting is a common aspiration and experience. Also, fathers are increasingly expected, urged, and motivated to become more engaged in the lives of their 
children. Involved fathering is typically viewed as beneficial for fathers, mothers, children, and society, at large (Harrington et al. 2014; Petts et al. 2018; Petts and Knoester 2020; Raub et al. 2018). Yet, it seems that resistance from business owners and those most concerned with corporate profits have particularly mobilized resistance to more generous paid parental leave offerings in the U.S. (Jacobs and Gerson 2004; Milkman and Applebaum, 2013; Pfau-Effinger 2005). Relatedly, the rise of neoliberalism and its market-based logic has deterred attempts at instituting more family-friendly social policies such as paid paternity leave (Jacobs and Gerson 2004; Peck 2010; Pfau-Effinger 2005; Valarino et al. 2018).

On balance, our conceptual framework and previous research suggest: Hypothesis \#1: Considerable support will emerge for paid paternity leave availability, generous lengths of leave offerings, and government funding of leaves-despite sparse availability of paid paternity leave offerings in the U.S.

Gendered Expectations and Preferences for Paid Paternity Leave Offerings in the U.S.

Yet, even beyond societal contexts, gendered expectations profoundly shape our views of the world and ourselves. As discussed above, gendered expectations are institutionalized throughout society, but they are also embedded in individuals' gender identities, role expectations, and worldviews (Lorber 1995; Ridgeway 2009; Risman 1998; 2018). Still, they are also continually negotiated, reified or challenged; sometimes, they are transformed (Lorber 1995; Risman 1998; 2018; West and Zimmerman 1987). For example, there is evidence of changes in gendered expectations over the life course and across generations, as challenges and changes to traditionally gendered identities, 
role expectations, and worldviews have become more common (Cotter et al. 2011; Gerson 2009; Yavorsky et al. 2015). Paid paternity leave-taking attitudes, policies, and practices may symbolize challenges to traditionally gendered expectations. Similarly, internalized gendered expectations may encourage particular family ideations, prompt different perceptions of self-interests, and result in various levels of support for paid paternity leave offerings (Harrington et al. 2014; Petts and Knoester 2020; Petts et al. 2018; Valarino et al. 2018).

Attitudes about paid paternity leaves offer a unique opportunity to consider how gendered expectations shape attitudes and preferences about the organization of work and families (Harrington et al. 2014; Petts et al. 2018; Valarino et al. 2018). For instance, how might internalized gendered expectations matter for paid paternity leave preferences in the midst of a milieu in which fathers are increasingly expected to be nurturing, involved parents - yet mothers are expected to be especially skilled, committed, and primary caregivers of children - and mothers have overwhelmingly transitioned into embracing paid work commitments and continued to fulfill the bulk of domestic work responsibilities? Might men or women be more likely to support more generous paid paternity leave offerings? Why? How might attitudes about involved fathering expectations, dual-earner couples, separate spheres, and intensive mothering be predictive of paid paternity leave preferences? Why?

Gender. First, one's gender is likely to predict attitudes about paid paternity leave offerings. On the one hand, buoyed by contemporary fathering expectations that often encourage greater levels of father involvement, men may be eager to support paid 
paternity leave-taking opportunities because these opportunities may allow them to intensively invest in childcare and other domestic responsibilities—and still fulfill breadwinning roles. Men often remark that they wished they had more time to spend with their children and that fathering is something that they cherish (Bianchi et al. 2006; Marsiglio and Roy 2012; Milkie et al. 2004). Consistent with these sentiments, men have dramatically increased their levels of father involvement in recent decades (Bianchi et al. 2006; Raley et al. 2012). Yet, they remain sensitive to traditionally gendered masculinity norms and although they overwhelmingly tend to take some time off of work after the arrival of a new child, men usually take only one week or less off (Petts et al., 2018; Thébaud and Pedulla 2016). Still, especially since fathers are the recipients of paid paternity leave offerings by definition, one might anticipate that men would be more likely than women to prefer that generous paid paternity leave offerings be made available, for their own self-interests.

On the other hand, because of traditionally unequal divisions of household labor and the recovery and challenges that accompany the arrival of a new child, women may be more likely than men to endorse generous paid paternity leave offerings and believe that paternity leaves may especially serve their own self-interests (Petts et al. 2018; Thébaud and Pedulla 2016; Valarino et al. 2018). Women may welcome the additional care and domestic help that paid paternity leaves may allow men to provide, while maintaining an income flow to the family. Also, women may anticipate the potential for paternity leave-taking to encourage heightened long-term commitments to childcare and domestic work from the men who take it. Paternity leaves, especially if they encourage 
men's greater commitments to domestic responsibilities, may also encourage and enable women to return to work sooner after the arrival of a child, invest more fully in advancing one's career, and commit to working a preferred number of hours per week (Pedulla and Thébaud 2015; Petts and Knoester 2020; Raley et al. 2012). These implications may be seen as especially salient, and increasingly so, as women continue to increase their presence and statuses in paid labor (Bianchi et al. 2006; Jacobs and Gerson 2004; Pedulla and Thébaud 2015; Stone 2007).

In sum, paternity leave may be seen as a means of easing women's parenting stress, increasing their feelings of well-being, boosting the quality of father-child relationships, modifying traditionally gendered divisions of labor, and enhancing women's opportunities for commitments and success in paid labor. In fact, there is research evidence that supports these potential consequences of paternity leave-taking (Petts and Knoester 2019; 2020; Petts et al. 2020; Pragg and Knoester 2017; Raub et al. 2018). Also, previous research that has compared men's and women's support for paid paternity leave availability with these same data found that women are more likely than men to endorse paid paternity leave (Petts et al. 2018). Thus, we anticipate finding this same result with our more refined models in the present study and further finding that women will also be more likely than men to endorse longer paternity leave offerings and government support for such offerings, too.

On balance, this leads to:

Hypothesis \#2: Because of traditionally gendered divisions and expectations for labor, and their links to family ideations and self-interests, women will be more likely than men 
to support paid paternity leave availability, longer lengths of leave offerings, and government funding of leaves.

Gendered parenting role attitudes. Second, gendered parenting role attitudes are expected to influence preferences for paid paternity leave offerings as individuals consider the family ideations and self-interests that are important to them. Consistent with recent research about the complexity of gender ideologies (Cotter et al. 2011; Knight and Brinton 2017; Scarborough et al. 2018), we expect that multiple dimensions of gendered parenting role attitudes shape paid paternity leave preferences. First, for example, involved fathering attitudes are likely to increase support for offering more generous paid paternity leaves. That is, individuals who are more supportive of involved fathering commitments may be more inclined to enable more engaged, nurturing fathering through more widespread and generous paid paternity leave offerings (Harrington et al. 2014; Petts et al. 2018; Valarino et al. 2018).

Nevertheless, there is evidence that attitudes about fathering may be relatively unimportant. Heightened expectations and expressed preferences for more involved fathering have long been present, yet women continue to disproportionately sacrifice careers, invest in domestic responsibilities, and take time off work after the arrival of a new child (Author citation; Kaufman 2020; Petts et al. 2018; Stone 2007). Also, on top of structural supports, perceptions of masculinity norms that are already in place at worksites and within social networks may be what matters most—and most U.S. fathers take very little paternity leave, even when it is available (Kaufman 2020; Petts et al. 2018; Thébaud and Pedulla 2016). Consequently, involved fathering attitudes may 
actually be more central to women's preferences for paid paternity leave offerings since they more commonly act as gatekeepers for parenting responsibilities and may be more motivated to encourage changes in fathering behaviors, compared to men (Collins 2019; Kaufman 2020; Petts and Knoester 2019).

Second, individuals who are more supportive of dual-earning expectations may be more inclined to help enable women's resumption of typical work commitments soon after the birth of a child through endorsing more generous paid paternity leave offerings (Petts and Knoester 2019; Petts et al. 2018; Winter 2008). For instance, women often recognize the need for leave support in order to achieve more egalitarian relationships and pursue career goals along with a partner (Collins 2019; Pedulla and Thébaud 2015; Stone 2007). Men may also be particularly supportive of more generous paid paternity leave offerings when they hold dual-earning expectations since there is evidence that they undertake more fathering responsibilities when they have partners who are employed full-time (Raley et al., 2012). Indeed, support for paternity leave-taking seems to be prioritized in societies where both women and men are encouraged and recognized to be prominent caretakers and earners (Author citation; Kaufman 2020). Yet, dual-earning expectations may be particularly meaningful for women's preferences for paid paternity leave offerings since they are most likely to feel the pressure or desire to opt out of fulltime employment commitments (Collins 2019; Kaufman 2020; Stone 2007)

Finally, gendered attitudes about intensive mothering and separate spheres of specialization may affect support for generous paid paternity leave offerings (Collins 2019; Hays 1996; Stone 2007; Petts et al. 2018). Intensive mothering refers to the 
extremely (if not impossibly) high expectations for modern mothering behaviors that have emerged. Mothers are presumed to be uniquely skilled, qualified, and well-suited to be primary caregivers of children and ought to invest as much of their time and resources into child development as possible. Without intensive mothering, children are thought to be disadvantaged. Still, many families attempt to adapt to these pressures by relying on other well-qualified caretakers or enrichment experiences to act as substitutes for intensive face-to-face mothering interactions, at times. Nonetheless, intensive mothering expectations have long encouraged beliefs that mothers should "opt out" of the labor force, if possible (Hays 1996; Knoester and Fields 2020; Stone 2007).

Furthermore, traditionally gendered attitudes about separate spheres of specialization assume that women's expertise and commitment in domestic labor paired with men's expertise and commitment in paid labor offer complementary and preferable divisions of family labor. Thus, generous paid paternity leave offerings may be less of a priority for those who endorse separate spheres (Gerson 2009; Hays 1996; Kaufman 2020; Stone 2007). Indeed, it is anticipated that intensive mothering and separate spheres expectations may dampen support for paid paternity leave-taking offerings because both sets of expectations suggest that mothers are preferred caregivers and that fathers are ancillaries. Yet, because of women's greater domestic workloads, the perceived sacredness of mothering, and the greater variance in women's work-family commitments and gendered attitudes, it may be that attitudes about intensive mothering and separate spheres will be more likely to determine women's paid paternity leave preferences as 
compared to men's preferences (Collins 2019; Hays 1996; Kaufman 2020; Raley et al. 2012; Stone 2007).

Thus, overall, we anticipate the following:

Hypothesis \#3: Gendered parenting role attitudes will shape paid paternity leave preferences such that supportive attitudes toward involved fathering and dual-earner couple expectations will lead to preferences for more generous paid paternity leave offerings. Attitudes that reflect separate spheres and intensive mothering preferences will be negatively associated with support for more generous paid paternity leave offerings.

Hypothesis \#4: Gender will interact with gendered parenting role attitudes such that women's preferences for paid paternity leave offerings will be more likely to be shaped by their parenting role expectations, compared to men's preferences.

Other Factors

Yet, other factors may confound these associations. Work commitments, family contexts, age, education, and self-identified conservatism may be linked to gendered expectations and paternity leave preferences (Cotter et al. 2011; Petts et al. 2018; Pew Research Center 2017; Valarino et al. 2018; Winter 2008). Greater family strains are likely to increase support for more generous paid paternity leave offerings because they may lead to a greater willingness to advocate for family supports and for men to become more invested in domestic work (Collins 2019; Petts et al. 2018; Valarino et al. 2018). These strains may stem from family responsibilities, commitments, and contexts (Bianchi et al. 2006; Collins 2019; Jacobs and Gerson 2004). 
Economic and social disadvantages may also encourage a perceived need of additional family supports such as paid paternity leave. Thus, lower economic statuses and being a racial/ethnic minority group member may be positively associated with support for generous paid paternity leave offerings (Petts et al. 2018; Winston 2014; Winter 2008).

Finally, age, education, and self-identified conservatism may be likely to influence leave preferences. Age reflects different generational contexts that individuals have experienced, with older generations being more immersed in traditionally gendered expectations and experiences. In contrast, younger generations are more supportive of changes toward more egalitarian work and family expectations and experiences—and are more likely to benefit from family policies that support new parents (Cotter et al. 2011; Gerson 2009; Jacobs and Gerson 2004; Petts et al. 2018; Pew Research Center 2011). Similarly, higher levels of education may encourage more critical thinking about the social construction of gender and challenges to traditionally gendered expectations, work and family organizations, and work/family policies (Cotter et al. 2011; Petts et al. 2018; Valarino et al. 2018; Winter 2008).

Self-identified conservatism is also likely to be associated with work/family commitment preferences and may shape paid paternity leave preferences (Collins 2019; Jacobs and Gerson 2004; Petts et al. 2018; Valarino et al. 2018). Social conservatives may be uncomfortable with the challenge to traditionally gendered expectations that paid paternity leave may encourage. Economic conservatives may be especially unwilling to support initiatives that may be expected to increase taxes, enlarge government operations, 
increase regulations, or reduce the profitability of businesses. Political tribalism dynamics further suggest that those who identify as more politically conservative may be more likely to obstruct and oppose social policies that are more commonly endorsed and associated with politically liberal initiatives, such as generous paid paternity leave offerings (Gault et al. 2014; Jacobs and Gerson 2004; Pew Research Center 2011; 2017; Valarino et al. 2018).

\section{METHOD}

Data for this study come from the 2012 General Social Survey (GSS). The GSS is an annual (or biennial) national survey of U.S. adults. We use data from the 2012 GSS because it uniquely contained a special module that asked questions about parental leave preferences. The questions inquired about one's preferences for paid parental leave availability, lengths of desired leave offerings, and the funding of leaves. The questions also asked about one's preferences for the division of paid parental leave between mothers and fathers, which we used to construct indicators of paid paternity leave preferences. We are aware of no other publicly available data that allow for a similarly comprehensive analysis of paid paternity leave preferences in the U.S.

Our analytic sample was restricted to the random subset of respondents who were asked these questions about paid parental leave and offered responses to them $(N=$ $1,089)$. The reduction in sample size from the entire 2012 GSS $(N=1,974)$ is primarily a function of who was asked the parental leave questions $(N=1,302)$; yet, we also eliminated the approximately $5 \%$ of respondents who were asked about paid parental leave availability but responded that they "don't know" if it should be available (since 
these respondents were not asked the follow-up questions). In addition, we dropped the approximately $10 \%$ of the respondents who answered in support of paid parental leave availability but answered "don't know" about whether or not fathers should be given any of it.

\section{Dependent Variables}

The dependent variables for this study consist of preferences for paid paternity leave offerings. The variables reflect responses to a hypothetical scenario about a couple who both work full-time, have a newborn child, and one of the parents stops working to care for the child. Respondents were asked if they think paid leave should be available for this couple and if so, how long that leave should be. If respondents endorsed paid parental leave availability, they were also asked about how the desired length of paid leave should be divided between the mother and father (i.e., all/most/half/some/none to the mother and the mirror inverse to the father) and who should pay for this leave: a) the government, b) the employer, c) both, or d) other sources.

From this information, we created three dependent variables. Support for paid paternity leave availability $(1=y e s)$ indicates that respondents felt that paid parental leave should be available and that the father should have at least some of it to use. Preferred length of paid paternity leave offering is calculated by multiplying the number of months that respondents reported that the couple should have available to them, by the proportion of leave that they thought should be allocated to the father; we use .25 as the approximation for "some" and .75 as the approximation for "most" (only 5 respondents indicated that the father should be allocated most or all of the couple's paid parental leave 
offering). Respondents who did not endorse any paid paternity leave availability had their preferred length of leave offering assigned to be 0 months long, since they did not support any offering of leave. Finally, government funding of leave reveals whether or not respondents think that not only should there be paid paternity leave offered, but also that the government should pay for at least some of the cost of funding the paid leave offering $(1=y e s)$. Similar to before, respondents who did not endorse any paid paternity leave availability had their preference logically assigned—this time, as not supporting any government funding of leave (i.e., $0=n o$ ).

\section{Independent Variables}

The independent variables consist of gender $(1=$ female $)$ and gendered parenting role attitudes. Parenting role attitudes indicate responses $(1=$ strongly disagree; $5=$ strongly agree) to gendered statements about different dimensions of family life. An indicator of perceptions of the lack of a need for more involved fathering, no need for men to be more involved in family, is coded to reflect levels of disagreement to the statement: "Family life often suffers because men concentrate too much on their work." Attitudes about dual-earner couples are based on responses to the statement: "Both the husband and wife should contribute to the household income." Attitudes about separate spheres consist of responses to: “Man's job is to earn money; a woman's job is to look after the home and family." Attitudes about intensive mothering are tapped by reactions to the statement: "All in all, family life suffers when the woman has a full-time job." The gendered parenting role attitudes about these dimensions of family life are modestly to moderately correlated (i.e., $r$ 's range from $.01-.44$ in absolute values; only the correlation 
between separate spheres and intensive mothering indicators is $>.25$ ) and do not present collinearity problems when entered as separate predictors into the models, based on the variance inflation factor indicators. Thus, for both theoretical and empirical reasons, we utilize them as independent predictors of attitudes about paid paternity leave preferences (Cotter et al. 2011; Knight and Brinton 2017; Petts et al. 2018; Valarino et al. 2018).

\section{Control Variables}

Control variables for the analyses include indicators of work commitments and family contexts. Self-reports of age, years of education, and conservatism ( 1 = extremely liberal; 7 = extremely conservative) are also used.

Unpaid work variables include standardized measures of the hours per week that respondents (and one's partner, if available) spend on a) housework and b) care of family members. Paid work indicators include dummies for full-time (i.e. 35-55 hours), overtime (i.e. $>55$ hours), part-time (i.e. 1-34 hours), and no employment. Full-time work is used as the reference category. In addition, partner employed signifies whether or not one has a partner working in paid labor $(1=y e s)$.

Family context measures consist of relationship status dummy variables (i.e., married/cohabiting/single; married is used as the reference category), number of children, and number of children in the household who under the age of 18 years old. Economic and social disadvantage indicators include household income (in $\$ 10,000$ 's), occupational type (i.e. dummies for professional/service/labor/other; professional is used as the reference category), and race/ethnicity (i.e. dummies for white/black/latinx/other; white is used as the reference category). 


\section{Analytic Strategy}

Our analytic strategy involves examining descriptive statistics about paid paternity leave preferences and then modeling preferences for paid paternity leave availability, length of leave offerings, and government funding of leaves. When modeling preferences for paid paternity leave availability and government funding of leaves, we use logistic regressions. We use ordinary least-squares regression when predicting preferences for length of leave offerings.

For each dependent variable, we begin by presenting results from our full additive model. Then, we include a model that contains a significant interaction effect(s), when a hypothesized interaction(s) is found to be significant. Tests for hypothesized interaction effects involving gender and parenting role attitudes were conducted in separate models. We then graphed each significant interaction effect and examined subgroups of men and women separately in order to better understand the implications of the interaction. We display the interaction effects as predicted probabilities from our full interaction models based on marginal effects calculations. We utilize Stata 14 for all analyses and present the results from the use of multiple imputation with chained equations to address missing data, using ten imputations.

\section{RESULTS}

First, we analyze the descriptive statistics about paid paternity leave preferences. As shown in Table 1, the descriptive statistics reveal that there is majority support for a modest level of paid paternity leave offerings in the U.S. In line with our first hypothesis, there is a sizable amount of support for paid paternity leave availability. In 
fact, over half of all respondents thought that paid paternity leave should be made available to a hypothetical dual-earning couple that had a new child. However, it seems that lengthy paid paternity leaves are not a priority. On average, respondents endorsed leave offerings of about five weeks (i.e., 1.18 months). We had anticipated more widespread support for generous paid leave offerings, consisting of multiple months of leave. Yet, consistent with aspirations to make leave more readily available, about $1 / 3$ of all respondents felt that paid paternity leave should be offered and that the government should provide at least some funding to support paid paternity leave offerings. Rarely did respondents think that the government should solely fund leaves, though (i.e., about 5\% of all respondents thought so). The most common preference for funding was to have the government and employer share the costs of funding leaves.

(Table 1 about here)

In addition, the descriptive statistics offer initial support for our second hypothesis about gender predicting paid paternity leave preferences. Women $(60 \%)$ were significantly more likely than men (46\%) to support paternity leave availability. Women were also more likely to support longer lengths ( 1.29 vs. 1.05 months) of paternity leaves and government funding (35\% vs 30\% support) of leaves, although even women cannot be said to support "generous" lengths of paternity leave, on average. In sum, there is sizable support for paid paternity leave availability, a preference for only modest lengths of paid paternity offerings, and moderate support for at least some government funding of paid leave. Also, women seem to be significantly more in favor of instituting more generous paid paternity leave offerings, compared to men. 


\section{Preferences for Paid Paternity Leave Availability}

Next, we use regression techniques to predict preferences for paid paternity leave offerings. The logistic regression results from predicting support for paid paternity leave availability are displayed in the first two models of Table 2. As displayed in Model 1 of Table 2, again consistent with our second hypothesis, there is evidence that women ( $b=$ $.57, p<.001 ; \mathrm{OR}=1.72$ ) are more likely to support paid paternity leave availability, compared to men. The odds ratio indicates that the odds of women supporting paid paternity leave are $72 \%$ higher than the odds of men supporting paid paternity leave. A more precise and intuitive interpretation can be obtained by recognizing the marginal effect of this relationship; this effect indicates differences in predicted probabilities based on the data being analyzed (Williams 2012). The average marginal effect of the gender difference in this model is .13 , indicating that women have a predicted probability of supporting paternity leave that is .13 higher than men. In support of our third hypothesis about the relevance of gendered parenting role attitudes, we also find that dual-earning expectations $(b=.21, p<.01 ; \mathrm{OR}=1.23)$ are positively associated with preferences for paid paternity leave availability. Its marginal effect is .05 . There is some more modest evidence $(b=-.14, p<.10 ; \mathrm{OR}=.88)$ that traditionally gendered attitudes in support of separate spheres of specialization lead to lower levels of support for paid paternity leave availability, too.

(Table 2 about here)

As shown in Model 2 of Table 2, as anticipated by our fourth hypothesis, there is evidence that gender interacts with parenting role attitudes in predicting preferences for 
paid paternity leave availability. Specifically, separate spheres attitudes are disproportionately negatively associated with support for paid paternity leave availability among women, compared to men. It seems that women (e.g., $b=1.24, p<.001$ for female and $b=-.27, p<.05$ for female*separate spheres) are particularly more likely than men to endorse paid paternity leave availability when they disagree with traditionally gendered attitudes about separate spheres specialization. The interaction effect is illustrated in Figure 1 by a display of predicted probabilities of support for paid paternity leave availability by gender and attitudes about separate spheres, using adjusted predictions at representative values applied to the Model 2 results. Women's predicted probabilities of supporting paid paternity leave availability range from $.44-.68$ based on their attitudes about separate spheres; meanwhile, men's probabilities of supporting leave availability barely change according to their attitudes about separate spheres (i.e., they hover around .47). More specifically, based on these data, women's predicted probabilities of supporting paid paternity leave availability are .68 when they strongly disagree with separate spheres specialization and only .44 when they strongly agree with separate spheres.

(Figure 1 about here)

\section{Preferences for Lengths of Paid Paternity Leave Offerings}

The OLS results from predicting preferences for lengths of paid paternity leave offerings are shown in Model 1 of Table 3. In accordance with our second hypothesis, we find that women $(b=.24, p<.05)$ suggest nearly a quarter of a month longer lengths of paternity leave offerings, compared to men. Also, dual-earning expectations $(b=.17, p$ 
$<.01)$ are positively related to preferences for longer lengths of paid paternity leave

offerings. Traditionally gendered attitudes about separate spheres $(b=-.12, p<.05)$ are negatively related to preferences for longer lengths of leave offerings. There is no evidence of an interaction effect between gender and gendered parenting role attitudes in predicting preferences for lengths of leave offerings.

\section{Preferences for Government Funding of Paid Paternity Leave Offerings}

Finally, Models 1 and 2 of Table 4 present the logistic regression results from predicting preferences for at least some government funding of paid paternity leaves. In Model 1, there is support for our hypothesis that gendered parenting role attitudes predict preferences for government funding of leaves. For example, dismissing a need for more involved fathering behaviors $(b=-.14, p<.05 ; \mathrm{OR}=0.87)$ is negatively associated with preferences for government funding. Beliefs about the lack of a need for more involved fathering have a marginal effect of -.03 . Also, dual-earning expectations $(b=.22, p<.05$; $\mathrm{OR}=1.24)$ are positively associated with preferences for some government funding of paid paternity leaves. Dual-earning expectations have a marginal effect of .04 in predicting support for government funding.

Consistent with our fourth hypothesis, as shown in Model 2 of Table 4, there is evidence of an interaction effect between gender and gendered parenting role attitudes in predicting preferences for government funding of paternity leaves. Compared to men's attitudes, women's attitudes about separate spheres seem to be markedly more influential to their support for government funding of leaves. Thus, once again, it appears that disagreeing with separate spheres particularly encourages women (e.g., $b=.81, p<.05$ 
for female and $b=-.26, p<.05$ for female*separate spheres) to support more widespread paid paternity leave; in contrast, attitudes about separate spheres do not seem to be very meaningful to men's support for government funding, on average. The interaction effect is depicted in Figure 2 by a display of predicted probabilities of support for government funding of paid paternity leaves, by gender and attitudes about separate spheres, using adjusted predictions at representative values applied to Model 2 results. Women's predicted probabilities of endorsing some government funding of paid paternity leaves range from .23-.41 based on their attitudes about separate spheres; men's predicted probabilities of supporting government funding hardly change based on their attitudes about separate spheres (i.e., they hover around .32). In particular, women have a predicted probability of .41 for supporting some government funding of paid paternity leave offerings when they strongly disagree with separate spheres. However, they only have a predicted probability of .23 for supporting some government funding of paid paternity leave offerings when they strongly agree with separate spheres.

(Figure 2 about here)

\section{DISCUSSION}

The purpose of this study was to analyze attitudes about paid paternity leave offerings in the U.S. We focused on the relevance of gendered expectations for paid paternity leave preferences. Specifically, we considered how gender and gendered parenting role attitudes may be connected to preferred family ideations and self-interests, and then translated into paid paternity leave preferences within the U.S. institutional context. First, we described respondents' preferences for paid paternity leave availability, 
lengths of leave offerings, and government funding of leaves. Then, we examined how gender and gendered parenting role attitudes may lead to patterns in these preferences. We review and contextualize our findings, below.

First, we hypothesized that there would be considerable support for paid paternity leave availability, generous lengths of leave offerings, and government funding of leaves - despite sparse availability of paid paternity leave offerings in the U.S. In fact, we found majority support for paid paternity leave availability, moderate support for at least some government funding of these leaves, and desires for relatively short leave offerings. That is, $53 \%$ of all respondents reported that a hypothetical couple with a newborn child should have paid paternity leave made available to them. Also, 1/3 of all respondents indicated that not only should leave be made available, but also that the government should fund at least some portion of paid paternity leaves. Finally, respondents suggested that about five weeks of paid paternity leave would be appropriate, on average. These descriptive findings replicate previously reported 2012 paternity leave availability preferences in the U.S. and contribute new and unique information about desires for the lengths of leave offerings and support for some government funding of paternity leave offerings (Petts et al. 2018; Valarino et al. 2018). Government funding of leave offerings is important because it indicates an increased institutionalization of leave and represents support for more widespread leave offerings beyond the discretion of an employer. Thus, government funding of leaves may ensure that leave offerings are more readily available and partially address inequalities in the ability to take paternity leaves, as well. Although, 
some systems for offering leaves effectively rely on payroll taxes (Kaufman 2020; Petts et al. 2018; Winston 2014).

Of course, these descriptive findings reflect preferences in 2012. A comparison of these findings with more recent public polling data results suggests that there has been a marked increase in support for paid paternity leave availability in recent years. Also, the demand for paid paternity leave offerings seems to exceed the supply of such offerings. For example, a nationally representative Pew Research study in late 2016 found that $69 \%$ of the U.S. endorsed paid paternity leave availability (Pew Research Center 2017). Also, a 2014 Boston College Study found that less than 1\% of a select group of over 1,000 fathers, $67 \%$ of whom had accesses to paid paternity leave, responded that paternity leave either should not be offered or that less than one week should be offered (Harrington et al. 2014). Thus, overall, it is clear that current public opinion preferences for paid paternity leave availability greatly exceed reports of actual paid paternity leave availability — less than $20 \%$ of all workers have access to paid paternity leave from their employers and only a handful of states offer paid paternity leave opportunities (Harrington et al. 2014; Kaufman 2020; Petts et al. 2018; Winston 2014).

Yet, consistent with previous work, the results of this study suggest that support for paid paternity leave is viewed as markedly less important than support for paid maternity leave per se or more generic paid parental leave offerings. For example, the 2012 GSS indicates that about $80 \%$ of respondents endorsed paid maternity leave availability. Similarly, $82 \%$ of Pew respondents believed that paid maternity leave should be available (Pew Research Center, 2017). In contrast, less than .5\% of respondents (i.e., 
5 total -2 of which supported paid paternity leave, but not paid maternity leave) in the present study advocated for fathers to receive more paid parental leave after the arrival of a new child, compared to mothers.

Nonetheless, support for paid paternity leave offerings can be viewed as important for all family members, not only because of the presumptive implications of paternity leave-taking for family well-being, but also because allies for paid paternity leave-taking are likely to be advocates for widely available forms of maternity leave and/or more general parental leave-taking offerings, as well (Kaufman 2020; Petts et al. 2018; Raub et al. 2018; Valarino et al. 2018). That said, maternity leave is seen as a priority, compared to paternity leave, not only because of the greater needs for mothers to recover and breastfeed after a birth, but also because mothers are thought to want to take more time off from work than fathers, after a birth. Most people also think that mothers should spend more time with their new babies, compared to fathers, also-consistent with traditionally gendered parenting role attitudes (Petts et al. 2018; Pew Research Center 2017; Raub et al. 2018).

Still, preferred lengths of paid paternity leave offerings remain quite modest in the U.S. Our finding that public opinion in 2012 seemed to advocate for about five weeks of paid paternity leave is in line with the more recent Pew research and Boston College findings, also (Harrington et al. 2014; Pew Research Center 2017). This is a modest amount of paid leave, since over $2 / 3$ of OECD countries currently guarantee at least 14 weeks of paid leave to fathers of infants and most OECD countries guarantee at least 6 months of paid leave for such fathers (Kaufman 2020; Raub et al. 2018). Nonetheless, 
about $70 \%$ of Americans say that it is important for new babies to have equal time to bond with their mothers and fathers and young adults prefer more egalitarian family arrangements (Gerson 2009; Pedulla and Thébaud 2015; Pew Research Center 2017). Thus, there seems to be a great deal of ambivalence about involved fathering and dualearner couple ideals, in the midst of the continued influence of neoliberalism, ideal worker norms, and gendered parenting role attitudes that emphasize breadwinning roles for fathers (Collins 2019; Gerson 2009; Jacobs and Gerson 2004; Petts et al. 2018; Thébaud and Pedulla 2016).

Turning to our regression results, we found that gender and gendered parenting role attitudes were important predictors of paid paternity leave preferences, as hypothesized. First, as anticipated, women were much more likely than men to support more generous paid paternity leave offerings. One interpretation of this finding is that women are more likely to want men to provide more childcare and domestic work contributions after the arrival of a new child than men are to yearn to offer these commitments. Indeed, women are often overwhelmed and inadequately rewarded for taking on their combinations of domestic and paid work responsibilities after a child arrives (Collins 2019; Yavorsky et al. 2015). Relatedly, men are disproportionately rewarded for their investments in paid labor. In fact, there is research evidence of a "fatherhood bonus" in men's wages and corresponding increases in men's hours of paid labor — or at least the maintenance of very high levels of labor force commitments-- after the arrival of a new child (Killewald 2013; Knoester and Eggebeen 2006; Knoester and Petts 2017; Knoester et al. 2007). Yet, having and taking even paid leave may have 
concerning negative effects on men's earnings (Kaufman 2020; Petts and Knoester 2018; 2019; Petts et al. 2018).

Another interpretation of the finding that women are more likely than men to support paid paternity leave availability is that women may see paid paternity leave availability as a pathway to securing more generous paid maternity leave offerings in the U.S. Indeed, there is a consensus that paid maternity leave is much more crucial for family well-being than paid paternity leave and that paid maternity leave is seen as being in women's self-interest, in particular (Collins 2019; Petts et al. 2018; Pew Research Center 2017).

Second, gendered parenting role attitudes were linked to paid paternity leave preferences. Endorsing dual-earning expectations appeared to consistently and significantly lead to increased support for more generous leave offerings. Involved fathering attitudes that recognized the downsides of too much engagement in paid work seemed to modestly increase support for government funding of leaves. In addition, separate spheres attitudes were negatively associated with desired lengths of paid paternity leave offerings; strongly disagreeing with traditionally gendered separate spheres was associated with endorsing about one half of a month more paid paternity leave, compared to strongly agreeing with separate spheres.

Furthermore, separate spheres attitudes seemed to especially shape some of women's leave preferences. Women were increasingly supportive of leave availability and government funding when they disagreed with traditionally gendered attitudes about separate spheres. In contrast, men's attitudes about separate spheres did not seem to 
shape their leave preferences. This finding is consistent with previous work that finds that men's own gender ideologies may matter little for their family preferences; instead, they may be most affected by their perceptions of masculinity norms. Oftentimes, these masculinity norms are thought to align with "ideal worker" norms and encourage devotion to paid labor (Thébaud and Pedulla 2016; Kaufman 2020; Knoester and Petts 2017; Petts et al. 2018). As previously noted, there are tangible financial rewards also associated with especially men's devotion to paid labor (Kaufman 2020; Killewald 2013).

These findings concerning gendered parenting role attitudes contribute to a more nuanced understanding of the multidimensional aspects of gender ideologies and their implications for family preferences and policies (Cotter et al. 2011; Knight and Brinton 2017; Scarborough et al. 2018). Specifically, for paternity leave preferences in the U.S., gendered attitudes about involved fathering, dual-earner couples, and separate spheres appear to have unique contributions to make. Furthermore, the consistent findings about the positive associations between attitudes in support of dual-earner couples and preferences for more generous paid paternity leave offerings point to the emerging push for more egalitarian gender role expectations in work and family life, as women continue to increase their statuses and visibility in paid labor and both men and women seek to embrace more flexible and equal family arrangements. Yet, attitudes about traditionally gendered separate spheres seem to particularly shape women's preferences (Gerson 2009; Kaufman 2020; Raley et al. 2012; Stone 2007; Thébaud and Pedulla 2016).

Finally, it is notable that age, education, and self-reported conservatism were consistently predictive of preferences for paid paternity leave offerings in expected ways- 
- although these factors were not part of our hypotheses in the present study. Not coincidentally, age and political conservatism are positively associated with traditionally gendered expectations for family life. Also, education is negatively associated with such expectations (Cotter et al. 2011; Gerson 2009; Pew Research Center 2011; 2017). In addition, age is also negatively associated with being in the midst of experiencing the family strains of raising young children and realizing the potential usefulness of paid paternity leaves; education is positively associated with the likelihood of challenging ideal worker norms and pursuing dual-earner careers; conservatism is frequently associated with concerns about public investments in family social policies (Collins 2019; Petts et al. 2018; Stone 2007; Valarino et al. 2018).

In terms of age, these findings may reflect not only self-interest in terms of the usability of paternity leave offerings, but also the gendered and family policy ideals of new generations of parents (Gerson 2009; Petts et al. 2018; Pew Research Center 2017; Yavorsky et al. 2015). These trends appear to be becoming more pronounced for those with more education (Cotter et al. 2011; Gerson 2009; Petts et al. 2018). As for conservatism, the results represent new findings from the GSS data and stem from more rigorous regression analyses than from the descriptive findings from Pew. Still, despite the political gap in support for paid paternity leave offerings, Pew found that most Democrats and Independents, as well as just over half of Republicans, supported paid leave in late 2016 (Pew Research Center 2017). Thus, in light of marked support for paid paternity leave in the general public, the continued absence of widespread paid paternity leave opportunities can be seen as an indictment on the U.S. political system (Gilens and 
Page 2014; Milkman and Applebaum 2013). Yet, support continues to grow for paid paternity leave offerings and there has been evidence of progress in instituting it in more businesses, the federal government, and even states, in recent years. Still, the vast majority of fathers do not have access to paid paternity leave offerings (Bellware 2021; Collins 2019; Kaufman 2020; Petts et al. 2018).

There are limitations of this research that we should note. First, the data are relatively old; thus, additional research that uses more recent data is needed. Still, no comparable data is widely available that can enable a similarly rigorous analysis of U.S. paternity leave preferences and their links to gender expectations, yet. Second, our indicators of paternity leave preferences could be better. The scenario offered in the GSS assumed that leave entitlements were to be divided amongst a couple, as is common in many countries, based on the arrival of a new child. In the U.S., leave entitlements are presumed to be allocated to individual workers, not to couples. In addition, the survey questions asked about leave offerings for a heterosexual couple; thus, additional research is needed to better understand how preferences for leave offerings may be connected to the gender, sexuality and partner statuses of the individuals who may have access to the leave offerings. Finally, we would have preferred to have information about attitudes about paid paternity leave offerings per se, including more detailed information about desires and intentions to take (or have one's potential partner take) leave. As part of this, we would have liked to have more detailed information about gendered (parenting) ideals, expectations, aspirations, and experiences. For example, more extensive measures and in-depth information from the respondents about their gendered parenting role 
attitudes would be better. In particular, the indicators of intensive mothering (i.e., attitudes about family suffering due to women working full-time) and a need for involved fathering (i.e., attitudes about family suffering due to men concentrating too much on their work) in the present study are adequate but less than ideal measures (Hays 1996; Knoester and Fields 2020; Marsiglio and Roy 2012; Raley et al. 2012; Stone 2007).

Nevertheless, this study advances research on paid paternity leave attitudes in the U.S. In the process, it offers insights into how gendered expectations are reflected and translated in preferences for paid paternity leave offerings. Gendered expectations are reflected in sizable support for modest offerings involving a very gendered aspect of work/family policy. Based on their paternity leave preferences, U.S. adults seem to be somewhat ambivalent about gendered parenting roles, abilities, and commitments—and the supports that should exist for paternity leave-taking, specifically. Furthermore, gendered expectations seem to shape paid paternity leave preferences; that is, gender and gendered parenting role attitudes consistently and significantly predict preferences for leave availability, desired lengths of offerings, and government funding of leaves.

Beyond these findings, this study outlines that satisfying paid paternity leave preferences still requires more fruitful collaborations between political participants, employers, and employees in the U.S. Instilling widespread paid paternity leave offerings could offer more flexible arrangements for work and parenting commitments, improve the quality of life for parents, and potentially improve different dimensions of family well-being if fathers are motivated and urged to take advantage of paid paternity leave 
offerings - yet, gendered expectations still need to be navigated (Harrington et al. 2014; Kaufman 2020; Petts and Knoester 2019; Petts et al. 2018; Pew Research Center 2017). In conclusion, the findings from this study suggest that support for more generous paid paternity leave offerings could be enhanced if family ideations continue to shift towards encouraging more dual-earning and egalitarian arrangements among couples. Also, support could be enhanced if more individuals perceive that paid paternity leave offerings are in their own self-interests. Typically, men have been less likely to recognize the benefits of paid leave-taking for their own self-interests and so the incentives and encouragement for their leave-taking may be especially important to nurture. Similarly, policies that enable paid leave for fathers could gain more support if paternity leavetaking initiatives are enfolded with other provisions that could garner broader coalitions of endorsement, such as more general family leave offerings. Finally, support for more generous paid paternity leave offerings could be enhanced politically if elected officials were more sympathetic to the usefulness of leave offerings; our findings suggest that younger, female, and less conservative political representatives may be most likely to endorse more generous leave offerings. Currently, the institutional context in the U.S. does not seem to be satisfying the desires of the people for more generous paid leave offerings for fathers (Kaufman 2020; Petts et al. 2018; Pew Research Center 2017; Valarino et al. 2018). Perhaps more concerted public policy efforts can be encouraged and enacted as quality of life initiatives and a more apparent need for family supports become particularly motivating influences, in the wake of a global pandemic (Bellware 2021). 


\section{REFERENCES}

Acker, Joan. 1990. "Hierarchies, Jobs, Bodies: A theory of gendered organizations." Gender \& Society 4:139-158.

Bellware, Kim. 2021. "Paid Family and Sick Leave Could Expand for the First Time in Decades Because of the Pandemic." Washington Post, February 6, 2021. Retrieved February 6, 2021 (https://www.washingtonpost.com/politics/2021/02/06/coronavirus-paid-leave/)

Bianchi, Suzanne M., John P. Robinson, and Milkie, Melissa A. 2006. Changing Rhythms of American Family Life. New York, NY: Russell Sage.

Blekesaune, Morten and Jill Quadagno. 2003. "Public Attitudes toward Welfare State Policies: A comparative analysis of 24 nations." European Sociological Review 19(5):415-427.

Collins, Caitlyn. 2019. Making Motherhood Work: How women manage careers and caregiving. Princeton, NJ: Princeton University Press.

Coltrane, Scott, Elizabeth C., Miller, Tracy DeHaan, and Lauren Steward. 2013. "Fathers and the Flexibility Stigma." Journal of Social Issues 69:279-302.

Cotter, David, Joan M. Hermsen, and Reeve Vanneman. 2011. "The End of the Gender Revolution? Gender role attitudes from 1977 to 2008.” American Journal of Sociology 117(1):259-289.

Gault, Barbara, Heidi Hartmann, Ariane Hegewisch, Jessica Milli and Lindsey Reichlin Cruse. 2014. "Paid Parental Leave in the United States: What the data tell us about access, usage, and economic and health benefits." Washington D.C.: 
Institute for Women's Policy Research.

(https://digitalcommons.ilr.cornell.edu/cgi/viewcontent.cgi?referer=https://www.g oogle.com $/ \&$ httpsredir $=1 \&$ article $=2608 \&$ context=key_workplace).

Gerson, Kathleen. 2009. The Unfinished Revolution: How a new generation is reshaping family, work, and gender in America. New York: Oxford University Press.

Gilens, Martin and Benjamin I. Page. 2014. "Testing Theories of American Politics: Elites, interest groups, and average citizens." Perspectives on Politics 12(3):564581.

Harrington, Brad, Fred Van Deusen, Jennifer Sabatini Fraone, and Samantha Eddy. 2014. “The New Dad: Take your leave.” Boston College Center for Work and Family. (https://www.fatherly.com/wpcontent/uploads/2015/04/BCCWF20The20New20Dad20201420FINAL.pdf).

Hays, Sharon. 1996. The Cultural Contradictions of Motherhood. New Haven, CT: Yale University Press.

Jacobs, Jerry A. and Kathleen Gerson. 2004. The Time Divide: Work, family, and gender inequality. Cambridge, MA, US: Harvard University Press.

Kaufman, Gayle. 2020. Fixing Parental Leave: The six month solution. New York: New York University Press.

Killewald, Alexandra. 2013. "A Reconsideration of the Fatherhood Premium: Marriage, Coresidence, Biology, and Fathers' Wages.” American Sociological Review 78(1):96-116. 
Knight, Carly R. and Mary C. Brinton, 2017. "One Egalitarianism or Several? Two decades of gender-role attitude change in Europe.” American Journal of Sociology 122(5):1485-1532.

Knoester, Chris and David J. Eggebeen. 2006. "The Effects of the Transition to Parenthood and Subsequent Children on Men's Well-being and Social Participation.” Journal of Family Issues 27:1532-1560.

Knoester, Chris and Victoria Fields. 2020. "Mother-child engagement in sports and outdoor activities: Intensive mothering, purposive leisure, and implications for health and relationship closeness." International Review for the Sociology of Sport 55(7):933-952.

Knoester, Chris and Richard J. Petts. 2017. "Parenting Stress among Disadvantaged Fathers." Family Relations 66:367-382.

Knoester, Chris, Richard J. Petts, and David J. Eggebeen. 2007. “Commitments to Fathering and the Well-being and Social Participation of New Fathers." Journal of Marriage and Family 69:991-1004.

Knoester, Chris, Richard J. Petts, and Brianne Pragg. 2019. "Paternity Leave-taking and Father Involvement among Socioeconomically Disadvantaged U.S. Fathers.” Sex Roles 81:257-271.

Lorber, Judith. 1995. Paradoxes of Gender. Yale University Press.

Marsiglio, William and Kevin Roy. 2012. Nurturing Dads: Social initiatives for contemporary fatherhood. New York: Russell Sage Foundation. 
Milkie, Melissa. A., Marybeth J. Mattingly, Kei. M. Nomaguchi, Suzanne M. Bianchi, and John P. Robinson. 2004. “The Time Squeeze: Parental statuses and feelings about time with children." Journal of Marriage and Family 66(3):739-761.

Milkman, Ruth and Eileen Appelbaum, 2013. Unfinished Business: Paid family leave in California and the future of U.S. work-family policy. Ithaca, NY: Cornell University Press.

Peck, Jamie. 2010. Constructions of Neoliberal Reason. Oxford: Oxford University Press. Pedulla, David S., and Sarah Thébaud. 2015. "Can We Finish the Revolution? Gender, Work-Family Ideals, and Institutional Constraint." American Sociological Review $80: 116-139$.

Petts, Richard J., Daniel L. Carlson, and Chris Knoester. 2020. "If I [Take] Leave, Will You Stay? Paternity leave and relationship stability.” Journal of Social Policy 49:829-849.

Petts, Richard J. and Chris Knoester. 2018. "Paternity Leave-taking and Father Engagement." Journal of Marriage and Family 80:1144-1162.

Petts, Richard J. and Chris Knoester. 2019.“Paternity Leave and Parental Relationships: Variations by gender and mothers' work statuses." Journal of Marriage and Family 81:468-486.

Petts, Richard J. and Chris Knoester. 2020. "Are Parental Relationships Improved if Fathers Take Time Off of Work after the Birth of a Child?" Social Forces 98:1223-1256. 
Petts, Richard J., Chris Knoester, and Qi Li. 2018. "Paid Paternity Leave-taking in the United States." Community, Work \& Family. doi: 10.1080/13668803.2018.1471589.

Petts, Richard J., Chris Knoester, and Jane Waldfogel. 2020. “Fathers' Paternity Leave-taking and Children's Perceptions of Father-child Relationships in the United States." Sex Roles 82:173-188.

Pew Research Center. 2011. "The Public Renders a Split Verdict on Changes in Family Structure." https://www.pewsocialtrends.org/2011/02/16/the-publicrenders-a-split-verdict-on-changes-in-family-structure/

Pew Research Center. 2017. “Americans Widely Support Paid Family and Medical Leave, but Differ Over Specific Policies.” https://www.pewsocialtrends.org/2017/03/23/support-for-paid-leave-policies/

Pfau-Effinger, Birgit. 2004. "Culture and Welfare State Policies: Reflections on a complex interrelation." Journal of Social Policy 34(1):3-20.

Pragg, Brianne and Chris Knoester. 2017. "Parental Leave Use among Disadvantaged Fathers." Journal of Family Issues 38(8):1157-1185.

Raley, Sara, Suzanne M. Bianchi, and Wendy Wang. 2012. "When do Fathers Care? Mothers' economic contribution and fathers' involvement in child care." American Journal of Sociology 117(5):422-1459.

Raub, Amy, Arijit Nandi, Alison Earle, Nicolas De Guzman Chorny, Elizabeth Wong, Paul Chung, Priya Batra, Adam Schickedanz, Bijetri Bose, Judy Jou, Daniel Franken, and 
Jody Heymann. 2018. "Paid parental leave: A detailed look at approaches across OECD countries." WORLD Policy Analysis Center, Los Angeles, CA.

Rege, Mari and Ingeborg F. Solli, 2013. "The Impact of Paternity Leave on Fathers'

Future Earnings.” Demography 50:2255-2277.

Ridgeway, Cecilia L. 2009. "Framed before We Know it." Gender \& Society 23:145160.

Risman, Barbara. J. 1998. Gender Vertigo: American families in transition. New Haven: Yale University Press.

Risman, Barbara J. 2018. Where the millennials will take us: A new generation wrestles with the gender structure. New York: Oxford University Press.

Rudman, Laurie A. and Kris Mescher. 2013. "Penalizing men who request a family leave: Is flexibility stigma a femininity stigma?”,Journal of Social Issues 69:322340.

Scarborough, William J., Ray Sin, and Barbara Risman, 2018. "Attitudes and the Stalled Gender Revolution: Egalitarianism, traditionalism, and ambivalence from 1977 through 2016." Gender \& Society 33:173-200.

Stone, Pamela. 2007. Opting Out? Why women really quit careers and head home, Berkeley: University of California Press.

Thébaud, Sarah, and David S. Pedulla. 2016. "Masculinity and the Stalled Revolution." Gender \& Society 30:590-617

Valarino, Isabel, Ann-Zofie Duvander, Linda Haas, Gerda Neyer. 2018. "Exploring Leave Policy Preferences: A comparison of Austria, Sweden, Switzerland, and the 
United States.” Social Politics: International Studies in Gender, State \& Society 25(1):118-147.

West, Candace and Don H. Zimmerman. 1987. "Doing Gender." Gender \& Society $1: 125-151$.

Williams, Richard. 2012. "Using the Margins Command to Estimate and Interpret Adjusted Predictions and Marginal Effects." The Stata Journal: Promoting communications on statistics and Stata 12(2):308-331

Winston, Pamela. 2014. "Work Family Supports for Low-income Families: Key research findings and policy trends." Washington D.C.: U.S. Department of Health and Human Services. Office of the Assistant Secretary for Planning and Evaluation. https://aspe.hhs.gov/basic-report/work-family-supports-low-income-families-keyresearch-findings-and-policy-trends.

Winter, Nicholas. J. G. 2008. Dangerous Frames: How ideas about race \& gender shape public opinion. Chicago: University of Chicago Press.

Yavorsky, Jill E., Claire M Kamp Dush, and Sarah J. Schoppe-Sullivan, 2015. "The Production of Inequality: The gender division of labor across the transition to parenthood." Journal of Marriage and Family 77(3):662-679. 
Table 1. Descriptive statistics for all variables used in the analyses

\begin{tabular}{|c|c|c|c|c|}
\hline & $\begin{array}{l}\text { Full Sample } \\
\mathrm{M}(\mathrm{SD}) \text { or } \% \\
\end{array}$ & $\begin{array}{c}\text { Male } \\
\text { M(SD) or \% } \\
\end{array}$ & $\begin{array}{c}\text { Female } \\
\mathrm{M}(\mathrm{SD}) \text { or } \% \\
\end{array}$ & \\
\hline \multicolumn{5}{|l|}{ Paid Paternity Leave Preferences } \\
\hline Paid paternity leave availability & $53 \%$ & $46 \%$ & $60 \%$ & $* * *$ \\
\hline Length of paternity leave offerings ${ }^{\mathrm{a}}$ & $1.18(1.71)$ & $1.05(1.60)$ & $1.29(1.60)$ & $*$ \\
\hline $\begin{array}{l}\text { Government funding for paternity leaves } \\
\text { Independent Variables }\end{array}$ & $33 \%$ & $30 \%$ & $35 \%$ & + \\
\hline $\begin{array}{l}\text { Female } \\
\text { No need for men more involved in family }\end{array}$ & $\begin{array}{c}54 \% \\
2.73(1.14)\end{array}$ & $2.56(1.09)$ & $2.88(1.17)$ & $* * *$ \\
\hline Dual-earner couples & $3.74(0.92)$ & $3.70(0.93)$ & $3.78(0.91)$ & \\
\hline Separate spheres & $2.51(1.18)$ & $2.61(1.18)$ & $2.43(1.17)$ & $* *$ \\
\hline \multicolumn{5}{|l|}{ Control Variables } \\
\hline Age & $47.03(17.64)$ & $46.38(17.95)$ & 47.5717 .41 & \\
\hline Education & $13.47(3.04)$ & $13.53(3.00)$ & $13.64(3.05)$ & \\
\hline Weekly hours spent on housework & $10.27(13.91)$ & $8.45(10.59)$ & $11.84(15.66)$ & $* * *$ \\
\hline Weekly hours spent on care for family & $18.21(30.40)$ & $11.78(23.34)$ & $23.71(33.77)$ & $* * *$ \\
\hline Partner's hours spent on housework & $6.59(14.07)$ & $9.83(16.78)$ & $3.82(10.99)$ & $* * *$ \\
\hline Partner's hours spent on care for family & $10.46(25.45)$ & $13.42(28.74)$ & $7.93(22.38)$ & $* * *$ \\
\hline Works full-time & $36 \%$ & $42 \%$ & $31 \%$ & $* * *$ \\
\hline Works part-time & $15 \%$ & $13 \%$ & $16 \%$ & $* *$ \\
\hline Works overtime & $11 \%$ & $16 \%$ & $7 \%$ & $* *$ \\
\hline Not working & $38 \%$ & $29 \%$ & $46 \%$ & $* * *$ \\
\hline Partner employed & $35 \%$ & $30 \%$ & $40 \%$ & $* * *$ \\
\hline Household income $\mathrm{b}^{\mathrm{b}}$ & $4.63(4.53)$ & $5.00(4.79)$ & $4.31(4.30)$ & $*$ \\
\hline Occupation: Professional & $23 \%$ & $24 \%$ & $22 \%$ & \\
\hline Occupation: Service & $21 \%$ & $21 \%$ & $20 \%$ & \\
\hline Occupation: Labor & $11 \%$ & $18 \%$ & $4 \%$ & $* * *$ \\
\hline Occupation: Other & $46 \%$ & $37 \%$ & $53 \%$ & $* *$ \\
\hline White & $65 \%$ & $68 \%$ & $64 \%$ & \\
\hline Black & $15 \%$ & $11 \%$ & $19 \%$ & $* *$ \\
\hline Latinx & $14 \%$ & $15 \%$ & $14 \%$ & \\
\hline Other race/ethnicity & $5 \%$ & $6 \%$ & $4 \%$ & \\
\hline Married & $45 \%$ & $45 \%$ & $44 \%$ & \\
\hline Cohabiting & $10 \%$ & $9 \%$ & $10 \%$ & \\
\hline Single & $46 \%$ & $46 \%$ & $46 \%$ & \\
\hline Number of children & $1.82(1.77)$ & $1.66(1.77)$ & $1.97(1.76)$ & $* *$ \\
\hline Number of children in household & $0.56(1.05)$ & $0.44(0.80)$ & $0.66(1.17)$ & $* * *$ \\
\hline Self-reported conservatism & $4.10(1.43)$ & $4.12(1.45)$ & $4.08(1.42)$ & \\
\hline $\mathrm{N}$ & 1,089 & 502 & 587 & \\
\hline
\end{tabular}

Note: ${ }^{a}$ In months ${ }^{b}$ In $\$ 10,000$ 's ${ }^{* * *} p<0.001 ;{ }^{* *} p<0.01 ; * p<0.05$ for significant gender differences, using two-tailed t-tests. 
Table 2. Regression results predicting support for paid paternity leave availability

\begin{tabular}{|c|c|c|c|c|c|c|}
\hline & \multirow{2}{*}{\multicolumn{3}{|c|}{$\begin{array}{c}(1) \\
\text { Available }\end{array}$}} & \multirow{2}{*}{\multicolumn{3}{|c|}{$\begin{array}{c}\text { (2) } \\
\text { Available }\end{array}$}} \\
\hline & & & & & & \\
\hline & b & SE & OR & $\mathrm{b}$ & $\overline{\mathrm{SE}}$ & OR \\
\hline \multicolumn{7}{|l|}{ Gendered Expectations } \\
\hline Female & 0.57 & 0.15 & $1.72 * * *$ & 1.24 & 0.33 & $3.47 * * *$ \\
\hline No need for men more involved in family & -0.07 & 0.06 & 0.93 & -0.07 & 0.06 & 0.93 \\
\hline Dual-earner couples & 0.21 & 0.08 & $1.23 * *$ & 0.21 & 0.08 & $1.23 * *$ \\
\hline Separate spheres & -0.14 & 0.07 & $0.88^{+}$ & 0.00 & 0.09 & 1.00 \\
\hline \multicolumn{7}{|l|}{ Control Variables } \\
\hline Age & -0.02 & 0.00 & $0.98 * * *$ & -0.02 & 0.00 & $0.98 * * *$ \\
\hline Education & 0.06 & 0.03 & $1.06^{*}$ & 0.06 & 0.03 & $1.06^{*}$ \\
\hline Weekly hours spent on housework & -0.17 & 0.09 & $0.84^{+}$ & -0.16 & 0.09 & $0.86^{+}$ \\
\hline Weekly hours spent on care for family & 0.04 & 0.09 & 1.04 & 0.05 & 0.09 & 1.05 \\
\hline Partner's hours spent on housework & 0.14 & 0.10 & 1.15 & 0.12 & 0.10 & 1.13 \\
\hline Partner's hours spent on care for family & -0.15 & 0.11 & 0.86 & -0.15 & 0.11 & 0.86 \\
\hline Works part-time $^{\mathrm{a}}$ & -0.13 & 0.22 & 0.88 & -0.14 & 0.22 & 0.87 \\
\hline Works overtime $^{\mathrm{a}}$ & -0.22 & 0.23 & 0.80 & -0.25 & 0.23 & 0.78 \\
\hline Not working ${ }^{\mathrm{a}}$ & 0.11 & 0.28 & 1.12 & 0.11 & 0.28 & 1.12 \\
\hline Partner employed & 0.26 & 0.22 & 1.30 & 0.29 & 0.22 & 1.33 \\
\hline Household income & 0.02 & 0.02 & 1.02 & 0.02 & 0.02 & 1.02 \\
\hline Occupation: Service ${ }^{b}$ & 0.20 & 0.21 & 1.22 & 0.20 & 0.22 & 1.22 \\
\hline Occupation: Labor ${ }^{\mathrm{b}}$ & -0.14 & 0.26 & 0.87 & -0.15 & 0.26 & 0.86 \\
\hline Occupation: Other ${ }^{b}$ & -0.03 & 0.28 & 0.97 & -0.04 & 0.28 & 0.96 \\
\hline Black $^{\mathrm{c}}$ & -0.10 & 0.20 & 0.91 & -0.09 & 0.20 & 0.91 \\
\hline Latin $^{c}$ & -0.06 & 0.20 & 0.92 & -0.09 & 0.20 & 0.91 \\
\hline Other race/ethnicity ${ }^{\mathrm{c}}$ & 0.13 & 0.31 & 1.14 & 0.13 & 0.31 & 1.14 \\
\hline Cohabiting $^{\mathrm{d}}$ & 0.12 & 0.26 & 1.12 & 0.11 & 0.26 & 1.11 \\
\hline Single $^{\mathrm{d}}$ & 0.24 & 0.24 & 1.28 & 0.26 & 0.24 & 1.29 \\
\hline Number of children & 0.06 & 0.05 & 1.07 & 0.06 & 0.05 & 1.07 \\
\hline Number of children in household & 0.06 & 0.08 & 1.07 & 0.06 & 0.08 & 1.09 \\
\hline \multicolumn{7}{|l|}{ Interactions } \\
\hline Female x Separate spheres & & & & -0.27 & 0.12 & $0.76^{*}$ \\
\hline $\mathrm{R}^{2}$ & & & .09 & & & .09 \\
\hline
\end{tabular}


Table 3. Regression results predicting preferred length of paid paternity leave offerings (in months)

\begin{tabular}{|c|c|c|}
\hline & \multicolumn{2}{|c|}{$\begin{array}{c}\text { (1) } \\
\text { Length }\end{array}$} \\
\hline & b & SE \\
\hline \multicolumn{3}{|l|}{ Gendered Expectations } \\
\hline Female & $0.24 *$ & 0.11 \\
\hline No need for men more involved in family & -0.05 & 0.05 \\
\hline Dual-earner couples & $0.17 * *$ & 0.06 \\
\hline Separate spheres & $-0.12 *$ & 0.05 \\
\hline \multicolumn{3}{|l|}{ Control Variables } \\
\hline Age & $-0.01 * *$ & 0.00 \\
\hline Education & 0.01 & 0.02 \\
\hline Weekly hours spent on housework & -0.03 & 0.07 \\
\hline Weekly hours spent on care for family & -0.09 & 0.07 \\
\hline Partner's hours spent on housework & 0.10 & 0.07 \\
\hline Partner's hours spent on care for family & -0.06 & 0.08 \\
\hline Works part-time ${ }^{\mathrm{a}}$ & -0.02 & 0.17 \\
\hline Works overtime ${ }^{a}$ & -0.02 & 0.18 \\
\hline Not working ${ }^{\mathrm{a}}$ & 0.27 & 0.22 \\
\hline Partner employed & -0.01 & 0.18 \\
\hline Household income & 0.02 & 0.01 \\
\hline Occupation: Service ${ }^{b}$ & $0.31^{+}$ & 0.16 \\
\hline Occupation: Labor ${ }^{\mathrm{b}}$ & 0.05 & 0.20 \\
\hline Occupation: Other ${ }^{\mathrm{b}}$ & 0.04 & 0.21 \\
\hline Black $^{\mathrm{c}}$ & 0.23 & 0.15 \\
\hline Latinx $^{c}$ & -0.12 & 0.15 \\
\hline Other race/ethnicity ${ }^{c}$ & 0.30 & 0.23 \\
\hline Cohabiting $^{\mathrm{d}}$ & 0.13 & 0.20 \\
\hline Single $^{\mathrm{d}}$ & 0.13 & 0.18 \\
\hline Number of children & 0.04 & 0.04 \\
\hline Number of children in household & 0.09 & 0.06 \\
\hline $\begin{array}{r}\text { Self-reported conservatism } \\
\text { Interactions }\end{array}$ & $-0.18 * * *$ & 0.04 \\
\hline Female x Separate spheres & & \\
\hline
\end{tabular}

$\mathrm{R}^{2} \quad \frac{.06}{\text { Note: Logistic regression results reported with odds ratios }(\mathrm{OR}) \text {, and }}$

pseudo $\mathrm{R}^{2}$. *** $p<0.001 ; * * p<0.01 ; * p<0.05 ;+\mathrm{p}<0.10$

${ }^{a}$ Reference category is work full-time; ${ }^{b}$ Reference category is

professional; ${ }^{\mathrm{c}}$ Reference category is white; ${ }^{\mathrm{d}}$ Reference category is married. 
Table 4. Regression results predicting support for some government funding of paid paternity leave offerings

\begin{tabular}{|c|c|c|c|c|c|c|}
\hline & \multicolumn{3}{|c|}{ (1) } & \multicolumn{3}{|c|}{ (2) } \\
\hline & & Fundi & & & Fund & \\
\hline & $\mathrm{b}$ & $\overline{\mathrm{SE}}$ & OR & $\mathrm{b}$ & $\overline{\mathrm{SE}}$ & OR \\
\hline \multicolumn{7}{|l|}{ Gendered Expectations } \\
\hline Female & 0.20 & 0.16 & 1.22 & 0.81 & 0.35 & $2.24 *$ \\
\hline No need for men more involved in family & -0.14 & 0.07 & $0.87^{*}$ & -0.14 & 0.07 & $0.87 *$ \\
\hline Dual-earner couples & 0.22 & 0.08 & $1.24 *$ & 0.22 & 0.08 & $1.24 *$ \\
\hline Separate spheres & -0.12 & 0.08 & 0.89 & 0.01 & 0.10 & 1.01 \\
\hline Intensive mothering via no full-time work & 0.04 & 0.07 & 1.04 & 0.04 & 0.07 & 1.04 \\
\hline \multicolumn{7}{|l|}{ Control Variables } \\
\hline Age & -0.02 & 0.01 & $0.98 * *$ & -0.02 & 0.01 & $0.98 * *$ \\
\hline Education & 0.07 & 0.03 & $1.07 *$ & 0.07 & 0.03 & $1.07 *$ \\
\hline Weekly hours spent on housework & 0.04 & 0.10 & 1.04 & 0.05 & 0.10 & 1.06 \\
\hline Weekly hours spent on care for family & -0.02 & 0.10 & 0.98 & -0.02 & 0.10 & 0.98 \\
\hline Partner's hours spent on housework & -0.08 & 0.11 & 0.92 & -0.10 & 0.11 & 0.91 \\
\hline Partner's hours spent on care for family & -0.19 & 0.12 & 0.83 & -0.19 & 0.12 & 0.83 \\
\hline Works part-time $^{\mathrm{a}}$ & -0.12 & 0.22 & 0.88 & -0.14 & 0.22 & 0.87 \\
\hline Works overtime ${ }^{\mathrm{a}}$ & -0.25 & 0.25 & 0.78 & -0.28 & 0.25 & 0.76 \\
\hline Not working ${ }^{\mathrm{a}}$ & 0.21 & 0.30 & 1.23 & 0.21 & 0.30 & 1.23 \\
\hline Partner employed & -0.09 & 0.26 & 0.92 & -0.07 & 0.26 & 0.94 \\
\hline Household income & 0.00 & 0.02 & 1.00 & 0.00 & 0.02 & 1.00 \\
\hline Occupation: Service ${ }^{\mathrm{b}}$ & 0.35 & 0.22 & 1.42 & 0.35 & 0.22 & 1.42 \\
\hline Occupation: Labor ${ }^{\mathrm{b}}$ & 0.36 & 0.28 & 1.43 & 0.34 & 0.28 & 1.41 \\
\hline Occupation: Other ${ }^{\mathrm{b}}$ & -0.12 & 0.30 & 0.89 & -0.12 & 0.30 & 0.88 \\
\hline Black $^{\mathrm{c}}$ & -0.11 & 0.21 & 0.90 & -0.10 & 0.21 & 0.90 \\
\hline Latin $^{c}$ & 0.09 & 0.21 & 1.09 & 0.08 & 0.21 & 1.09 \\
\hline Other race/ethnicity ${ }^{\mathrm{c}}$ & 0.28 & 0.31 & 1.32 & 0.28 & 0.31 & 1.32 \\
\hline Cohabiting $^{\mathrm{d}}$ & -0.07 & 0.27 & 0.93 & -0.08 & 0.27 & 0.92 \\
\hline Single $^{\mathrm{d}}$ & -0.22 & 0.27 & 0.80 & -0.21 & 0.27 & 0.81 \\
\hline Number of children & -0.04 & 0.06 & 0.96 & -0.04 & 0.06 & 0.96 \\
\hline Number of children in household & 0.28 & 0.08 & $1.32 * *$ & 0.28 & 0.08 & $1.32 * *$ \\
\hline Self-reported conservatism & -0.27 & 0.05 & $0.76^{* * *}$ & -0.28 & 0.05 & $0.76^{* * *}$ \\
\hline Interactions & & & & & & \\
\hline Female x Separate spheres & & & & -0.26 & 0.13 & $0.77 *$ \\
\hline $\mathrm{R}^{2}$ & & & .09 & & . & .09 \\
\hline
\end{tabular}

Note: Logistic regression results reported with odds ratios (OR), and pseudo $\mathrm{R}^{2} .{ }^{* * *} p<0.001 ;{ }^{* *} p<0.01$;

$* p<0.05$

$+\mathrm{p}<0.10^{\mathrm{a}}$ Reference category is work full-time; ${ }^{\mathrm{b}} \mathrm{Reference}$ category is professional; ${ }^{\mathrm{c}} \mathrm{Reference} \mathrm{category}$ is white;

${ }^{\mathrm{d}}$ Reference category is married 
Figure 1. Predicted probabilities of supporting paid paternity leave availability

0.80

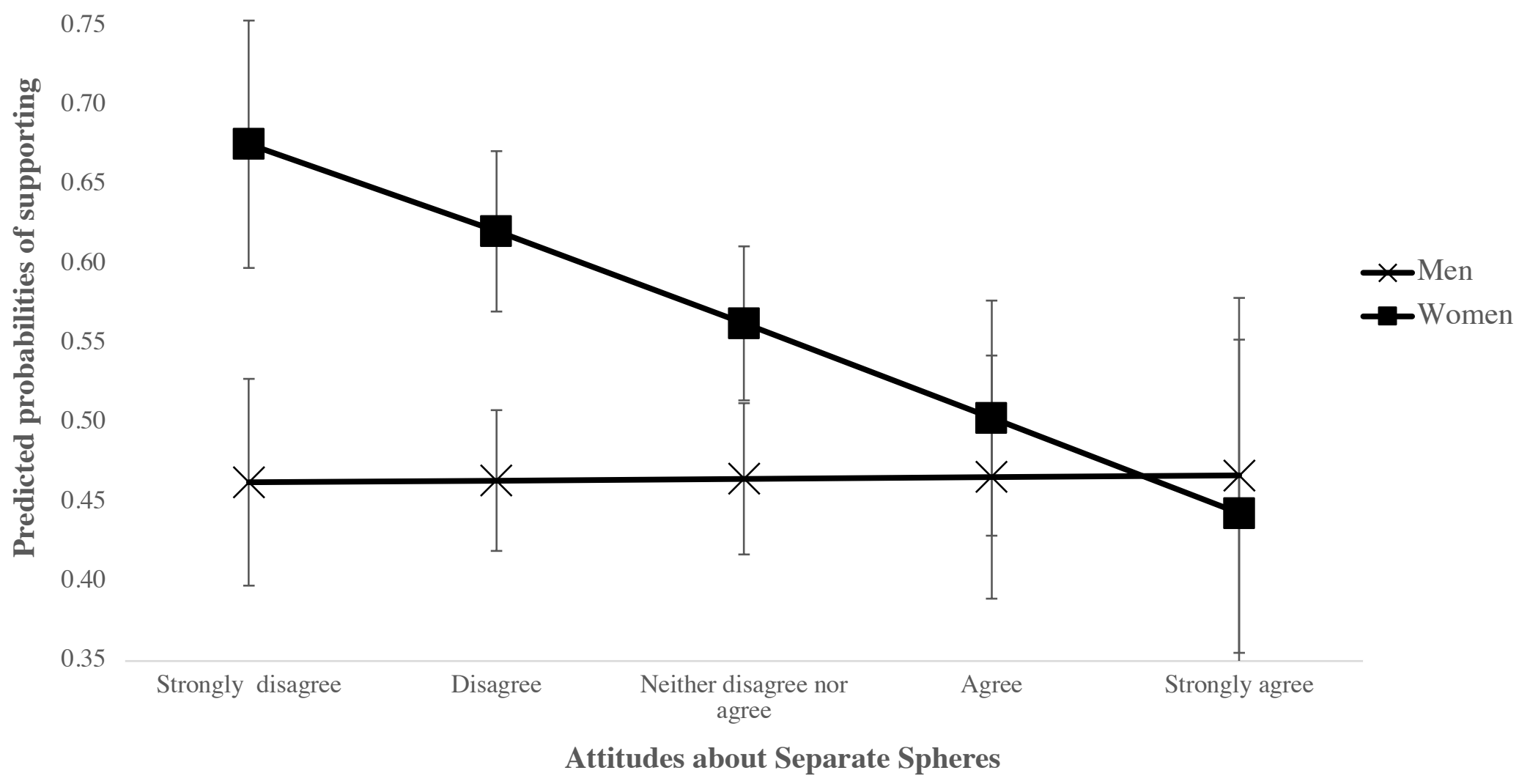

